\title{
Schooling and Ethnocultural Communities in Canada: Alternatives for Planning A Post-Modern Century
}

\author{
Stacy Churchill \\ University of Toronto \\ and \\ Isabel Kaprielian-Churchill \\ California State University at Fresno
}

This essay examines trends in education that affect Canadian schools.

As in most countries the US debate on the place of ethnic and cultural communities in education is strongly influenced by national, state, or even local politics with little reference to outside influences. It is ironic to note that at the same time the 1998 NAES National Conference was being held in Fresno, CA, the campaign to establish Proposition 227, which would have the capability to impact several linguistic minorities, was well under way. The proposition essentially aimed at eliminating most bilingual education programs and was approved by California voters in June, 1998. The very size of the population of a state like California-with a population greater than that of a geographically huge country like Canada (about $32 \mathrm{~m}$. Vs. 29 $\mathrm{m}$. in 1998)-means that statewide political debates on topics 
such as affirmative action and bilingual education can be won and lost almost without reference to other states or regions of the United States, much less to foreign countries.

In short-term politics no one gains advantage from comparisons with other jurisdictions. But we do contend that comparisons can be very important for reflection and long-term planning of the type that was the central theme for the 1998 NAES meeting. In the following we argue that Canada can be viewed as a sort of laboratory for changes that are fundamentally reshaping the agenda of world education, changes that have long-term planning implications for the United States. This argument does not suggest that models borrowed from Canada or anywhere else can or should be transplanted into U.S. schools, certainly not without major adaptation and modification. Changing education is difficult, and no one should pretend that borrowed models constitute a panacea. Instead, our focus is on major trends that affect issues outside education changes in the way people view nations, nationalities and citizenship. These changes have direct relevance to education. We will show how these changes are reflected, at least partially, in some aspects of Canadian education.

To approach our topic we will briefly note distinctive characteristics of the U.S. decision-making context and then turn to the Canadian laboratory, starting with changes to the concept of nation and citizenship and then describing specific schooling models relevant to minority communities.

\section{Distinctive Aspects of U.S. Educational Policy}

Planning for better schools in the twenty-first century promises to be extremely difficult in most of the United States. Existing models of education that serve the disadvantaged are being dismembered and destroyed by misinformed criticism that feeds on latent racism and prejudice against the poor of all ethnic and linguistic origins. These changes can be traced to the rise of neoconservatism in the 1970's, heralded by attacks on the "inefficiency" of desegregation measures and continued by a generalized attack on the role of government and the growth of "entitlements" (Wirt 5-18). The impact was equally visible with respect to policies on bilingual education. In the decade of the 1980s only one piece of legislation was passed 


\section{Ethnic Studies Review Volume 22}

to increase the permissible scope of bilingual education: Colorado changed its prescriptive legislation removing a substantial portion of its entitlements; the existing California legislation was pushed by the governor into lapsing through "sunset" provisions, and efforts were made to alter laws in Texas and Illinois in the same direction (Sacken and Medina).

The approval of Proposition 227 by California voters in the June 1998 primaries-a proposition essentially aimed at eliminating most bilingual education programs-is only one additional entry in a long series of attempts to build on popular fears and propose radical solutions that feed into the neoconservative agenda. The fears are fanned by media accounts and are widely held (Crawford), but the overwhelming evidence of research and the consensus of respected academics contradicts them (Cummins). Such a contradiction between informed opinion and political action raises many questions. We leave to others the discussion of how power relationships in society shape minority schooling (Darder) and instead ask a question: What rationale is so powerful that even well-meaning media and opinion leaders seem unable to call a spade a spade, unable to point out the negative impacts of such changes on the educational chances of children from ethnic and linguistic minority groups?

The rationale, the "glue" that holds together against the force of evidence and reason, is the goal of schooling citizens; not just any citizens but good, upstanding American citizens. Like most observers we would agree with this goal, just as we endorse the goal of the French or Polish governments of schooling good, upstanding French or Polish citizens and, so on, from country to country. The problem arises when the rationale of schooling good citizens gets clothed in a very limited version of what a citizen should be in a contemporary nation, a limited version that reduces citizenship to having one language and one culture-each the "official" one, thus allowing as little diversity as possible.

The debates on multiculturalism in public school curricula and textbooks mirror the nationalistic tone summarized in the title of a famous study on school reform: $A$ Nation at Risk. This study of multicultural politics and education policy-making in New York and California by Cornbleth and Waugh begins its 
discussion of the contemporary debate by focusing on historical debates in the US: Nativism, discrimination against newcomers, and resurgent neonativist movements in the 1990s. The authors trace current neonativist feeling to confusion between two types of nationalism, ethnic versus civic. One US version of nationalism, they note, is civic nationalism based on "the people" defined in "universalistic terms of human rights and citizenship," but "neonativists conflate ethnicity and nationality" ( 35). They further note that Britain and Canada have a civic identity based upon allegiance to a parliamentary and legal system and symbols such as the Crown. And, indeed, the case studies they present in the remainder of the book provide abundant evidence of how rationales for opposing recognition of diversity in curricula are grounded in a neonativist vision of uniformity, a uniformity that strongly suggests the only good American is an American who lives "up" to the unified standards of language and culture of white Anglo-American tradition. The ethnic roots may be disguised, but for persons who do not share the roots, the implications are obvious.

There is evidence that US policy has made accommodations to diversity and that, at least during the period from about 1955 to the late 1970s, tended to move in the same direction as policy in other advanced industrialized countries. $A$ study which one of the authors helped direct for the OECD1 provides what remains the most detailed contemporary portrayal of educational practices and policies for linguistic and cultural minorities across different countries. A key finding of the study is relevant for planning: Even though their political debates on education evolved in almost exclusively national terms, most of the countries (with the important exception of Japan, a non-participant in the study) had followed a long-term pattern of evolution that was similar in direction. In the period up to about 1955 all but a small handful had ignored educational issues related to non-mainstream cultures and languages, but a little over 20 years later all except Japan had developed policies that (a) recognized the need to take into account divergent languages and cultures and (b) evolved towards a far greater recognition of those languages and cultures than anyone might have dreamed possible at the beginning of the period (Churchill 1986; Allardt, Noah and Sherman). 
Long-term trends appear to sweep through education, even though the individual countries affected do not consult or consciously copy each other (Churchill 1998), and US education has not been exempt from this process. It is our contention that planning for US futures in education should take into account worldwide trends that have a potential relevance. The one we deal with here is the long-term decline of the nationstate, which is particularly relevant to planning for education in a multicultural, multiethnic, multiracial future.

\section{The Decline of the Nation-State}

The observation of converging patterns of minority education policy in different countries leads us to two major assertions: first, world-wide trends in the evolution of governmental processes have a direct relevance for what is likely to happen to education in the United States in the long term, if not necessarily in the immediate future; second, this evolution directly affects the way individual countries view the nature of concepts as fundamental as citizenship duties, national languages, and national cultures. In the following, we sketch some of the directions that such evolutionary processes have taken and then show how they relate to certain models of education that have emerged in Canada within the last two decades-models that may give much food for thought to those looking at the future of US education in relationship to languages and cultures outside the Anglo mainstream. Just as California politics and culture are sometimes regarded as a laboratory where popular fantasies are acted out on a trial basis then packaged into media and marketed to the world, so we believe Canada is a laboratory where extraordinary developments are occurring in the evolution of the most imperial of all the inventions of modern Europe-the nation-state as it emerged by the year 1900, the nation-state that is the model for organizing all modern societies on the face of the earth. It is the model usually based on the concept of "one people, one language, one state" who together form the nation.

We have reviewed these trends related to the nation-state in a recent lead article of the International Review of Education (Churchill) and will only summarize here a few of the salient forces at work. A variety of authors have identified major forces 
that are converging to change what citizens can expect their national governments to control and/or do for them. Some see the challenge in terms of culture-the penetration of "foreign" ideas by means of satellite, internet or multinational corporations. As a former French Minister of Culture phrased it: "...might the truth be more ominous: the higher the satellite, the lower the culture? The disappearance of languages and cultural forms is the great risk today. Diversity threatens to be replaced by an international mass culture without roots, soul, color, or taste" (Lang 43). Some express fear but others embrace openly an ethic of consumerism, progress in communications, the spread of trends in dress and habit that erase national identities (Ohmae). But behind all the trends of socalled globalization most see a rising merchant economy that obliterates national borders to make way for the triumph of a new world order based upon concentration of capital in transnational corporations controlled by a class of super-rich persons who owe allegiance to no one and have successfully defied any national government to tax their profits and financial transfers in a significant way (Saul 144-45, Thurow).

What does all of this have to do with minority education? Everything, in our opinion. The entire structure of public schooling as it exists today in both industrialized and non-industrialized societies is based upon the idea of a national government that provides a common education to prepare citizens to live as members of a people who, collectively, are "the nation" united by a common language, culture, and loyalty. Only a handful of states have made accommodations to permit meaningful development of separate languages and cultures. Until recently in the European world the main examples were Switzerland, Belgium and Finland. The much-touted Soviet and Yugoslav models have now been revealed for the sham that they always were-centralized political control through bureaucracies that manipulated different national symbols to perpetuate dominance by one or two ethnocultural groups within a dictatorial framework that permitted no organized opposition. Stripped of the shell of jargon, the model is the same one that has been the model of both right and left wing governments in the former colonial world, almost without exception.

But what happens to the whole apparatus of one lan- 
guage-one culture-one nation, when the nation-state enters into decline and can no longer control its own economy, its own culture, its own mode of life? What happens to minorities when the dominant national culture is under threat? Do they become the scapegoats of frightened governments determined to eliminate internal differences, as if these differences would save the so-called national culture and language from a broader erosion? Or does the diversity within the individual country become the stake in the battle for survival, as the "nation" takes on new meaning and as diversity is converted from a problem into a resource, to borrow a distinction from Ruiz (3-25)?

It appears highly likely that the western industrialized world is on the verge of a major transition-to a world where sovereignty plays a very different role, the world of the post-modern nation-state. We see this new form of nation-state as redefining the concept of nation to accept diversity as an integral component of citizenship. A few countries are playing a significant role as laboratories of change. The most visible is the European Union. The European Union provides a model of attempted transnational regulation and control almost, but not quite, on the same plane as the transnational forces of capitalism that it seeks to control.2 An attempt is being made to create a new economic and political order that uses the remaining elements of national sovereignty to protect divergent cultures and social systems. And a handful of states, particularly Canada and Spain, are at the forefront of experimentation with new models of internal structure that permit the nation-state to play a strong and useful role for the foreseeable future. Outside the western industrialized world the other most likely candidates for creating new models of viable nation-states are perhaps India and South Africa.

In turn, a prime function of governments would be to preserve the diversity of cultural and linguistic community structures within nation-states against the homogenizing forces of globalization.

\section{Canada as a Source of Models}

The case can be made that Canada is emerging as a jurisdiction with unusual characteristics that make it a candidate for becoming in the not distant future one model of "post-modern 
nation-state," even if there is probably no consensus as to what a post-modern nation-state might be. Space does not permit developing this theme in detail, but it would be important to understand certain basic factors at work in the Canadian scene.

The ideas of the authors have emerged in part as a result of having done two coast-to-coast interview studies, one in the 1980 s, another in the 1990s. Both were focused closely on elements related to what it means to be Canadian and, specifically, a Canadian living as a "minority," that is as a numerical minority in a province or territory with a different cultural group as the dominant mainstream. The first was a study related to a federal program that subsidizes education for the "official linguistic minorities" in Canada's provinces and territories, as well as the teaching of English and French the two "official languages," as a second language in the provincial education systems (Churchill in association with Peat Marwick and Partners). The second was a review of the relationships between these English and French linguistic minorities in each province with the majority group of the province and, more specifically, with the so-called "ethnic communities," citizens whose ethnocultural origin is from elsewhere in the world than France or the British isles (Churchill and Kaprielian-Churchill 1991).

For the sake of brevity, we may suggest the following aspects of Canadian law and political structures as indicative of something growing progressively more unusual in terms of the dimensions of sovereignty. All of these aspects have developed rapidly in the last thirty years.

1. Official bilingualism is a fact of life. About 98 per cent of Canadians speak either English or French or both official languages, though the vast majority speak only one of the two languages. 3 The federal government has made massive strides toward providing services in French and English to all citizens, and a number of English-dominant provinces have moved towards developing services in French. Quebec has always provided basic bilingual services to its English-speaking minority.

2. The status and role of French-speaking Canadians have been transformed in the last three decades. From virtual second-class social and economic status (even in Quebec) in the 


\section{Ethnic Studies Review Volume 22}

period before roughly 1960, French-speaking Canadians have gone through a massive social transformation. All significant aspects of political and economic control within Quebec are dominated by French-speakers, and in other provinces significant progress has been made in providing education and public services in French, most notably in New Brunswick and, to a lesser extent, in Ontario. (The latter two provinces are the home of about three-quarters of the French-speaking population outside Quebec, roughly 750,000 out of 1,000,000.)

3. An interesting by-product of the current legal structure is that individual citizens have specific, constitutionally guaranteed rights that are, at least in theory, transferable between provinces and territories. The most important of these is the right of parents to have children schooled in English or French, wherever numbers are sufficient to justify such schooling. 4

4. While accepting the existence of two official languages, the Canadian government and constitution have not converted the two related "cultures" into official cultures. The motivation for this is the widespread impression among persons who are not of French or Anglo-British descent, that recognizing culture officially would base the Canadian state on ethnicity rather than open citizenship. Instead of two official cultures, an official policy of multiculturalism has been proclaimed at the federal level, linked with a loose form of constitutional recognition.

5. Combining the recognition of two official languages for the provision of federal government services with an official policy of multiculturalism has had important symbolic implications: individuals may be free to feel fully "Canadian" while continuing to speak another language in most or all of their daily lives and to adhere to their own culture, however defined.5

6 . The Canadian governmental system is among the most decentralized in the modern world. Provinces have powers almost unheard of in any other federative system, and they continue to joust for more power. Canadian provinces have a long record of negotiating agreements with the Federal Government that confer on them one form or another of special status. New Brunswick is the only province that, in all aspects of its governance, is officially bilingual. Quebec, on the other hand, is officially bilingual in terms of the Canadian constitution with respect to the operations of its legislature, the vot- 
ing of laws and the operation of the courts-even though its legislature has proclaimed the province unilingual French. (The law in question, like all other laws down to the present day, was only valid when voted and proclaimed in bilingual versions, and provisions that contradicted constitutional provisions were gradually eliminated through court challenges). On such crucial issues the Canadian provinces are a checkerboard of diversity. For example, representatives of the Quebec government have a major role in selecting immigrants (a federal responsibility) who intend to reside in Quebec, thus exercising a de facto control over access to citizenship for potential immigrants.

7. In cultural matters while Ottawa has control of foreign affairs, provinces are responsible for education. To square the circle, official delegations to organizations such as UNESCO are made up of a mixture of federal and provincial officials.

8. The native peoples of Canada-persons of Amerindian and Inuit (previously "Eskimo") descent-are progressively referred to as First Nations. The change in vocabulary emphasizes a growing consensus that persons of aboriginal descent should enjoy certain rights that predate the occupation of the North American continent by European settlers. The existence of rights predating treaties with European powers has been recognized in a variety of Canadian court decisions, even if the practical, political and legal implications remain a matter of dispute.

9. The model of official bilingualism and multiculturalism became a model for aspirations of First Nations together with their demands for a form of sovereignty over territories they hold or claim. The present Northwest Territories with a territory of $1,323,000$ square miles $(3,426,000$ square kilometers) is now governed by a territorial legislative body in which English and French share their role as official languages along with four indigenous languages. In 1990 a decision was made to separate off the vast eastern portion of the territory, to be named Nunavut. As of 1999 Nunavut will be controlled for all intents and purposes by the Inuit people, whose language will be a territorial official language alongside English and French.

In summary Canada houses a social and legal complexity that defies the simple tenets of old-style sovereignty. At the 
same time, it is also the industrialized country whose sovereignty is most vulnerable to transnational forces. Most Canadian industry is under U.S. ownership; most television viewed in the country comes from U.S. sources, and most films are produced in the U.S. Two U.S. magazines alone receive more advertising from Canadian sources than all Canadianbased magazines put together. The conclusion of the North American Free Trade Agreement merely consecrated a continental domination of the United States over its northern neighbor in almost all domains.

This, then, is the volatile mix out of which post-modern Canada is emerging: a country that is officially bilingual in French and English, where multiple cultures are recognized through an official policy of multiculturalism, viewed as the opposite of official biculturalism, where indigenous peoples have asserted rights and are being bargained with increasingly as First Nations rather than as wards of the state that can be disposed of at the will of the majority as represented in Parliament.

Sovereignty looks very different north of the border, as does the concept of citizenship. Not surprisingly the educational implications of this changed mix are also very different.

\section{Emerging Models of Education}

The recognition of non-mainstream groups and their claims in education has become the central issue in the evolution of schooling in Canada and many other countries. The political nature of the problem reflects an important dimension of state activity, one which often was overlooked in the past. We borrow from Raymond Breton the concept of "symbolic allocation of resources" as being a function of government on a par with the allocation of physical and financial resources that are already recognized in the economic role of the state. (Breton 122-44). This function has given rise to a new form of political bargaining that is particularly relevant to schooling, what the Canadian political philosopher Charles Taylor calls "the politics of recognition." This new function of the state, as embodied in public schools, is at the heart of everything from the demands for affirmation of multicultural identities in the curriculum to the debate over bilingual education in California. 
The Canadian political evolution sketched above has given rise to a variety of forms of educational practice whose value and implications are highly variable. In the following we will deal only with three forms that appear most illustrative: education for persons of recent immigrant extraction, French immersion schools for English-speaking children, and the constitutionally guaranteed schooling for official linguistic minorities, English in Quebec and French elsewhere. Readers must keep in mind that these official linguistic minorities have a different status from other minorities.

Our studies of the evolution of programs for immigrant and refugee children (Kaprielian-Churchill and Churchill 1993, 1994) confirm a fundamental willingness of school authorities to make major curricular adjustments to accommodate children who are new to Canada ( McLeod; Samuda, Berry and Laferrière). On the other hand no general provision exists to allow most children to have access to forms of bilingual education that are equivalent to the U.S. practice of transitional bilingual education, i.e. using a mother tongue other than English or French to teach school subjects while the child (speaking a third language as mother tongue) gradually acquires the main provincial language of instruction (French in Quebec, English elsewhere). Instead of such transitional bilingual programs, all provinces require immigrant children (including children born in Canada to immigrant parents and speaking a home language that is not English or French) to study fulltime in the dominant provincial language. Meanwhile, the children are supposed to receive instruction in English as a second language (or French as a second language in Quebec). Failure to provide instruction in the mother tongue is a singular shortcoming in Canadian educational policy that has been strongly criticized by advocates of equal educational opportunity (Cummins and Danesi; Corson and Lemay).

On the other hand, most provinces permit voluntary access (where enrollments suffice to offer them) to programs that are variously termed "heritage languages" or (a more recent euphemism) "international languages," along with a number of parallel programs that emphasize African Canadian cultural heritage. In Quebec a limited number of "classes d'accueil," or reception classes, are provided to assist children, but 
they are generally of very short duration. Programs for elementary schools in the English-dominant provinces usually relegate heritage languages and black studies to times outside the regular school day. Alberta and Manitoba do have, however, a limited number of Ukrainian language immersion programs, often serving third and fourth generation UkrainianCanadians. Canadian studies have repeatedly shown that teaching children in their mother tongue, even in the admittedly weakened environment of after-hours and Saturday school classes with teachers drawn from their communities, does not detract from their achievement in English and other school subjects but in most cases has a positive effect on achievement (Cummins and Danesi ).

A legitimate question arises as to why Canadian authorities have not allowed transitional bilingual education and instead insist on ESL (or FSL) in circumstances where provision of quality instruction is not easily ensured. One study exists of the policy process. In Ontario, the province which receives on average nearly three out of every four immigrants to Canada, the evolution towards a better model of bilingual education ran into a wall of resistance from the provincial Ministry of Education in the early 1970s. The Board of Education of the City of Toronto attempted to set up transitional bilingual classes in response to strong demands from a number of immigrant parent groups. In response, the Ministry of Education issued a formal order to stop programs that used any language other than English or French as a medium of instruction for the regular curriculum. Although much has been done in the interim to ensure widespread availability of heritage language education in all school boards where a demand exists, the formal prohibition remains in effect down to the present (Churchill and Kaprielian Churchill 1994). Similarly, the methods for receiving, assessing and placing new immigrant students are very much under the autonomous control of local school authorities. A study in Ontario showed a situation that was unregulated and highly variable, even though some of the major school boards had put in place systems that were quite efficient (Kaprielian-Churchill and Churchill 1992).

The idea is purely speculative, but one has the sense that the major adaptation to deal with French-English issues in the 
late 1960s and the 1970s used up the flexibility of policy makers in the English-dominant provinces, leaving them fearful of letting loose any new potential targets for ethnic nationalism and racism at a time when they were struggling to cope with changes to improve conditions for the French minorities.

At present bilingual education programs have been set up to serve First Nations and Inuit in a few locations. The programs are highly variable and range from studying an aboriginal language as a subject to using such a language as the main medium of instruction (very few instances). Generalizations are extremely difficult, except to say that welldeveloped transitional bilingual programs exist only in a very few places and affect comparatively few children. However, rapid evolution appears likely and a recent overview of the literature provides a starting point for those interested in charting progress in the future (Corson and Lemay).

The two other models generated in the last decades, fortunately, have had better results and have a better prognosis for the future. It was in Canada that the French immersion model took root and spread providing impetus to the development of related programs in the U.S. called "dual immersion." In a typical form parents enroll their English-speaking children in kindergarten, where all play and other school readiness activities are conducted under the guidance of teachers and aides who speak only French to the children. In the early years of primary school all instruction occurs in French, with reading of English phased in gradually, starting perhaps in grade three. The astounding results in terms of functional bilingualism became an instant "hit" with the Canadian public and, progressively, with educators in many other countries (Swain; Johnson and Swain). Other forms of immersion exist, beginning later in the elementary school careers of the children and involving a variety of mixes in the use of French and English as media of instruction.

The unusual characteristic of the immersion model is less that it worked than the fact that it enjoyed and continues to enjoy such great popularity in English-speaking Canada. In provinces which are stereotyped as being anti-French, newspaper headlines began in the 1970s to trumpet the case of English-speaking parents spending the night outside immer- 
sion schools to enroll their children in the new programs. Today in most provinces the success of French immersion is so great that more English-speaking children are studying in French than do children of the French-speaking minority -- sometimes several times as many English as French in a province (Churchill 1998).

The final model is that of the French linguistic minorities in the different provinces outside Quebec. In the early 1960s the English minority in Quebec already enjoyed a complete, high quality educational system that included elementary and secondary schools, community colleges, and excellent universities, all operating in English and mainly under control of English-speakers. By contrast, in the mid-1960s the only existing minority French schools that remained after a century when English-dominant provinces forbade their creation or attempted to close them down were elementary systems in New Brunswick and Ontario. The latter were poorly equipped and had teachers with deficient qualifications. The main conquest of the last thirty years has been the expansion of French-language minority education for the from coast to coast. This was cemented in place by a 1982 constitutional amendment that provides a permanent guarantee of publicly funded elementary and secondary education for the official linguistic minorities of all provinces and territories.

Progress was rapid after 1967 in Manitoba, New Brunswick, and Ontario. Today all ten provinces have French schooling, though the systems are still extremely new in the provinces with the smallest numbers of French speakers. It was only at the beginning of 1998 that the final decisions were made to give the minority control of schools in all provinces after more than a decade of court battles and resistance to the constitutional requirement of control.

The results of these schools are astounding for persons who have trouble understanding that minorities can be bilingual and successful. The most studied creation of schools in a difficult environment occurred in Ontario. Starting in 1967-68, the creation of fully French-language high schools virtually eradicated the dropout of French students before the twelfth year of schooling. In the final thirteenth year required of those going on to university education, the new schools completely trans- 
formed the prospects for the French speakers. Enrolled in public English high schools before 1967, the French had only one-sixth or about 17 per cent of the chances of progressing from grade nine to grade thirteenth as compared to non-French students in the same schools. Five years after the schools had been created the time for the first cohort to move up the difference had narrowed so that the gap had narrowed to only about 85-90 per cent of the non-francophone rates. However in the schools that persisted in forcing the French to take most of their programs in English, the so-called "mixed" or "bilingual" high schools, the relative chances of the French only moved up to about 50 per cent of the non-francophone rate. As a result of studies under the direction of one of the authors of this article, these mixed schools were phased down in the late 1970s before being abolished following the approval of the constitutional change in 1982 (Churchill et al. 1978; Churchill, Frenette and Quazi ).

The most important consequences of overall policies in the field of official languages have to do with the conservation and maintenance of minority French-speaking communities in the Anglo-dominant provinces. With the exception of northern New Brunswick and certain areas in Ontario that border on Quebec together with southern Quebec and Montreal these areas make up what are called "the bilingual belt," the main areas of language contact (between French and English) in Canada where the rates of assimilation of French minorities have been a source of major concern for generations. Originally, the concern was mainly that of the French themselves in their struggle to survive as an identifiable group. Progressively, however, their existence as minorities has come to symbolize a certain definition of Canada as a nation-state, a symbol of a national citizenship where citizens of both language groups can coexist.

Beginning with the 1986 census, the results of policies to promote the French language and French education outside Quebec became visible. Exogamy, that is marriage between a minority French speaker and a non-Francophone in Englishdominant provinces, has always been associated with a tendency not to transmit French to the children of the couple as a mother tongue. Stated plainly, children with one French-speak- 


\section{Ethnic Studies Review Volume 22}

ing parent were mainly taught English. Exogamy, or marriage to English-speakers, has been a prime factor in the process of assimilation of the minorities, similar to what happens to immigrants from different countries (Landry and Allard 561-92). But the 1986 census showed a reverse trend, an increase in the percentage of mixed English-French marriages whose children learn French as a mother tongue. As a noted demographer commented: "In brief, in the country as a whole, the dominance of English over French, which is still very significant [in the mixed marriages analyzed], has been cut in half within thirty years" (Lachapelle 22).

The link between community survival and schooling in the light of inevitably high rates of exogamy has now been established in terms that, frankly, are more optimistic than any community leader or political advocate of minority schooling would have dared hoped. Landry and Allard, whose pioneering work on the concept of ethnolinguistic vitality is at the center of very active research, have shown that the effects of exogamy in terms of assimilation can almost be eliminated if the parents agree to speak the minority language at home and send their children to the French-language minority schools (Landry and Allard 561-92).7

The conclusion to be drawn is that French-language schools combined with a decision in the family to speak the minority language regularly (though not exclusively) to the children virtually overcomes the assimilation factors associated with exogamous marriages. Since exogamy remains the most powerful force acting for assimilation, there is a clear signal that using the French minority schools as a tool, families can conserve their linguistic and associated cultural heritage (O'Keefe).

The total impact of the minority school system can thus be perceived. First, American readers should note that minority French youth in the English-dominant provinces (except for a few areas of northern New Brunswick) who retain their mother tongue also speak English virtually without a trace of an accent. This point is little emphasized in Canadian research, since it is so self-evident to the public at large. Learning and studying in French in youth is not perceived today as an obstacle to speaking and working in English in adult life. The 
Canadian issue today is whether French schooling will reduce assimilation. On this point the research by Landry and Allard has provided a strong defense of the schools. At the same time introducing the minority school system across the country has drastically reduced the gap in educational achievement between French and English. This is what is known as a winwin situation.

\section{Conclusions}

From this overview we can see that the Canadian mix of models of schooling for linguistic minorities includes one weak contribution and two very promising models. The weak contribution refers to the failure of Canadian provinces to advance in the direction of transitional bilingual schooling for persons of immigrant descent. What has been done in this respect, the teaching of heritage languages, supports research in other countries pointing to the strong positive influence of teaching in the minority tongue for general achievement and for achievement in the majority language. The first strong model is that of French immersion for teaching French as a second language to English speakers; this model is already well known and has served in part to stimulate similar experimentation in the U.S. and other countries. The second strong model is that of the minority school under minority control. The creation of schools for the French minorities has had two parallel effects: (a) reducing drastically the dropout rates in ways that have had a major impact on socio-economic conditions of the minority and (b) increasing drastically the possibilities for the minority community to pass on its heritage to future generations.

Canada offers a model of education of minorities based upon an evolving definition of the nation-state. The Canadian nation-state of today is, at best, a work in progress. No historical fatality ensures that the experiments of the last thirty years will endure the pressures of power and politics in the contemporary world.

Changes in Canada are deserving of closer attention by American scholars because they have arisen as the by-product of a worldwide trend, the decline of the traditional nation-state. This decline is raising new issues about the role of schools in "producing" citizens and, in particular, is a powerful trend that 
runs counter to the revival of nativism in the U.S. The novel responses of the Canadian educational system do not provide simple models that can immediately be transferred to Lansing, Michigan, or San Diego, California. Rather they illustrate dimensions of a problem of minority education that are likely to be of importance to the U.S. in the future. Educators and members of the public interested in planning for new types of relations between schools and ethnocultural communities can benefit from examining assumptions of their discussion in the light of such major trends.

\section{WORKS CITED}

Allardt, E. "Implications of the Ethnic Revival in Modern, Industrialized Society. A Comparative Study of the Linguistic Minorities in Western Europe." Commentationes Scientiarum Socialium (12) (Helsinki: Societas Scientiarum Fennica, 1979).

Breton, Raymond. "The Production and Allocation of Symbolic Resources: An Analysis of the Linguistic and Ethnocultural Fields in Canada." Canadian Review of Sociology and Anthropology, 21 (1984): 123-44.

Churchill, Stacy. The Education of Linguistic and Cultural Minorities in the OECD Countries (Avon: Multilingual Matters 1986).

"Policy Development and Education in Multicultural Societies: Trends and Processes in the OECD Countries," in Centre for Educational Research and Innovation (CERI), Multicultural Education. (Paris: Organisation for Economic Cooperation and Development, 1987): 64-99.

\section{Public Opinion Support for Official Languages} Policies. (Ottawa: Department of the Secretary of State, 1993).

"The Decline of the Nation-State and the Education

of National Minorities." International Review of Education/ Revue Internationale de Pédagogie. 42, 4 (1996): 265-90. 
Churchill-Schooling

Official Languages in Canada: Changing the Language Landscape. Les langues officielles au Canada: Transformer le paysage linguistique. (Ottawa: Department of Canadian Heritage, 1998).

Frenette, Norman, and Quazi, Saeed. Éducation et Besoins des Franco-Ontariens. Le diagnostic d'un système d'éducation, 2 vols. (Toronto: Conseil de l'éducation francoontarienne/Ministère de l'éducation, 1985).

Churchill, Stacy, in association with Peat, Marwick and Partners. Evaluation of the Official Languages in Education Program. Final Report. Ottawa: Program Evaluation Directorate, Secretary of State, Canada, May 1987

Churchill, Stacy and Isabel Kaprielian-Churchill, The Future of Francophone and Acadian Communities in a Pluralistic Society: FACING PLURALISM. Preface by Maxwell Yalden, Canadian Commissioner of Human Rights. (Ottawa: Fédération des Communauteés Francophones et Acadienne du Canada, 1991).

Churchill, Stacy and Isabel Kaprielian-Churchill. "Evolution of Policies for Pluralism in Toronto Public Schools since 1965: Shifting Problem Definitions and Policy Responses," (Paper presented to Social Science History Association, Atlanta, Oct. 1994).

Churchill, Stacy, Brock Rideout, Mohindra Gill, and Raymond Lamerand. French Language Instructional Units. An In-Depth Study of Selected School Boards (Toronto: Ministry of Education, Ontario, 1978).

Cornbleth, Catherine, and Dexter Waugh. The Great Speckled Bird. Multicultural Politics and Education Policymaking (New York: St. Martin's Press, 1995).

Corson, David. Social Justice and Language Policy in Education: The Canadian Research (Toronto and Lemay, Sylvie: OISE Press, 1996) 
Crawford, James). Bilingual Education: History, Politics, Theory, and Practice. 3rd ed. (Trenton, N.J.: Crane Press, 1995).

Cummins, Jim. "Beyond Adversarial Discourse: Searching for Common Ground in the Education of Bilingual Students." Presentation to the California State Board of Education, Feb. 9, 1998." [http://ourworld.compuserve.com/homepages/ JWCRAWFORD/cummins.htm]

Cummins, Jim. "The Minority Language Child," in S. Shapson and V. D'Oyley (eds.) Multicultural Education: Canadian Perspectives (Clevedon, Avon: Multilingual Matters, 1984): 7192.

Cummins, Jim, and Marcel Danesi. Heritage Languages: The Development and Denial of Canada's Linguistic Resources (Toronto: Our Schools/ Our Selves Education Foundation, 1990).

Darder, Antonia. Culture and Power in the Classroom. A Critical Foundation for Bicultural Education. (Toronto: OISE Press, 1990).

Johnson, R.K., \& M. Swain. (Eds.) Immersion education: International perspectives (Cambridge: Cambridge University Press, 1997).

Kaprielian-Churchill, Isabel and Stacy Churchill. The Pulse of the World: Refugees in our Schools (Toronto: OISE Press, 1994).

Final Report. The Family-School Interface in Ontario Schools: Improving the Identification, Orientation, Assessment and Initial Placement of New Immigrant Children. (Toronto: Modern Language Center, Ontario Institute for Studies in Education, September 1993).

Lachapelle, Réjean. "Evolution of Language Groups and the official Languages Situation in Canada," in Canadian Issues . Demolinguistic Trends and the Evolution of Canadian 
Churchill-Schooling

Institutions. (Montreal: Association for Canadian Studies, 1989).

Landry, Rodrigue, and Réal Allard. "L'exogamie et le maintien de deux langues et de deux cultures: le rôle de la francité familioscolaire." Revue des sciences de l'éducation, 23, 3 (1997): 561-592.

Lang, J. "The Higher the Satellite, the Lower the Culture." New Perspectives Quarterly, 8, 4 (1991): 42-45.

McLeod, Keith A. (ed.) Multicultural Education: the State of the Art: Studies of Canadian Heritage. (Toronto: Canadian Association of Second Language Teachers, 1995).

Noah, Harold J., and Joel D. Sherman. Educational Financing and Policy Goals for Primary Schools. General Report. (Paris: Organisation for Economic Co-operation and Development, 1979).

Ohmae, Kenichi. The End of the Nation State: The Rise of Regional Economies. (New York, Free Press Paperbacks, 1995).

O'Keefe, Michael. Francophone Minorities: Assimilation and Community Vitality: New Canadian Perspectives (Ottawa: Department of Canadian Heritage, 1998).

Ouellet, Fernand. Lower Canada 1791-1840: Social Change and Nationalism, translated and adapted by Patricia Claxton, (Toronto: McClelland and Stewart, 1980).

Ruiz, R. "Orientation in Language Planning," in S.L. McKay \& S.C. Wong (Eds.) Language Diversity: Problem or Resource? (New York: Newbury House, 1988): 3-25.

Sackend, Donald M. and Marcello Medina Jr. "Investigating the Context of State-Level Policy Formation: A Case Study of Arizona's Bilingual Education Legislation." Educational Evaluation and Policy Analysis, 12, 4 (1990): 389-402. 
Ethnic Studies Review Volume 22

Samuda, Ronald J., John W. Berry, and Michel Laferrière. Multiculturalism in Canada: Social and Educational Perspectives. (Toronto \& Boston: Allyn and Bacon, 1984).

Saul, John Ralston. The Unconscious Civilization. (Concord, Ont.: Anansi, 1995).

Swain, Merrill. "French Immersion in Canada," in J. Cummins (Ed.), Bilingual Education, Volume 5, The Encyclopedia of Language and Education. (Dordrecht, Holland: Kluer Academic Press, 1998).

Taylor, Charles. Multiculturalism and The Politics of Recognition (Princeton: Princeton University Press, 1992).

Thurow, Lester C. The Future of Capitalism. How Today's Economic Forces Shape Tomorrow's World (New York: Penguin Books, 1996).

Wirt, Frederick M. "Neoconservatism and National School Policy," Educational Evaluation and Policy Analysis, 2, 6 (1980): 5-18.

\section{Endnotes}

1 The North American Free Trade Association (NAFTA), formed by the United States with Canada and Mexico, does not play any role similar to the European Union, except for reduction of tariff and non-tariff barriers to trade. The methods for conflict resolution within NAFTA are weak and, given the impunity with which the US government wields its economic power in spite of treaty obligations, provide no effective checks or balances to corporate power.

2 The figure is based on self-reporting on the national census and includes, therefore, all residents of Canada, including persons born abroad and persons whose mother tongue is neither English nor French.

3 Limitations on this right apply to naturalized citizens educated outside Canada. 
4 Symbolic legitimation does not mean that individuals do not have to deal with day-to-day racism and prejudice of other citizens who disagree with the official policies, but at least the drift of official policy is in a direction of recognizing diversity as legitimate.

5 See below for discussion of immersion programs as a form of language pedagogy.

6 Landry and Allard (1997) amassed a large database of intensive measures of language behavior on some 5000 youth and children from across Canada. In their most recent study of this information, they were able to demonstrate two powerful factors. (a) First they compared children of both endogamous and exogamous marriages-in-marriages versus out-marriages-and confirmed through a variety of measures of linguistic performance the very high levels of language loss, or subtractive bilingualism, found among the children. (b) Secondly, the researchers then identified within the sample two groups. In group one were those children whose parents spoke French in the home to their children and who placed their children in French minority schools (French as medium of instruction). In group two were children from families who sent their children to other schools operating mainly or exclusively in English. They then examined the implications of exogamy in terms of the two milieu: high family-h index. In this case the results were astounding in homes with a high family-school French index; there was almost no difference in language outcomes for the children between endogamous and exogamous marriages (Landry \& Allard).

Stacy Churchill University of Toronto \& Isabel Kaprielian-Churchill California State University at Fresno 